\title{
THE FUNCTION OF THE LOWER FEDERAL COURTS AS PROTECTORS OF CIVIL LIBERTIES
}

\author{
Osmond K. Fraenkei*
}

The judicial power of the United States lies in a Supreme Court and such inferior courts as Congress may create, and the jurisdiction of these courts extends to all cases arising under the Constitution. ${ }^{1}$ Since the Constitution, with its amendments, contains many provisions guaranteeing civil rights to individuals, it is evident that the federal courts have an important role to play in giving meaning and efficacy to civil liberties.

By virtue of the federal character of our government this is a dual role: the courts are concerned with violations of civil rights by both the states and the Federal Government. Despite the absence of specific authority in the Constitution, the Supreme Court early began to exercise the right to review such violations where it concluded they had infringed rights constitutionally guaranteed. This power has been used increasingly in recent years in cases affecting civil liberties. The Supreme Court's function in this field in reviewing state decisions has been frequently and fully discussed. By now, even though the Court's action in a particular case may still cause surprise, its function is generally understood. Less well known, however, is the role of the lower federal courts in dealing with such liberties.

Although the Constitution clearly authorizes Congress to invest the lower federal courts with jurisdiction over all cases arising under it, that body did not effectively do this for nearly a century. In the original Judiciary Act of 1789 , Congress gave no express power to the inferior federal courts which were then established to determine controversies arising under the Constitution. Such power was given, of course, as part of the grant of jurisdiction based on diversity of citizenship, but this was limited to controversies involving more than $\$ 500 .^{2}$ In 180r Congress for the first time granted the direct power to deal with cases arising under the Constitution, regardless of citizenship, but almost immediately withdrew $\mathrm{it}^{3}$ and it was not until 1875 that the power was definitely made part of the federal judicial system. ${ }^{4}$ The application of the new provision was, however, limited by the requirement

* Author: The Sacco-Vanzetti Case (r931); Our Civil Liberties (r944); Editor, The Curse op Bigness, Miscellaneous Papers of Mr. Justice Brandeis (1935). Author of legal articles in various publications. Member, Board of Directors of American Civil Liberties Union; Chairman, Hearings Board of Department of Welfare of City of New York.

${ }^{1}$ U. S. Const. Art. III, $\S \S I$ and 2.

2 Act of Sept. 24, 1789, c. 20, \$9; I STAт. 76.

'Act of Feb. 13, I80r, c. 4, \$1 2 ; STAT. 89, repealed 2 StAT. 132 (I80r).

4 Act of March 3, 1875, c. r37, 5I; I8 STAT. 47, now 36 Stat. Iogr (I911), as amended, 28 U. S. C. $\$_{44}$ (I) (1940). 
that a monetary claim be involved. In 1887 the amount was increased from $\$ 500$ to $\$ 2,000 ;^{5}$ since rgII it has stood at $\$ 3,000$. $^{6}$

With respect to certain limited constitutional issues, however, Congress gave the federal courts jurisdiction without regard either to diversity of citizenship or to the amount involved as early as $187 \mathrm{I}$. These provisions were part of the various civil rights laws by which Congress sought to implement the post-Civil War amendments. They dealt primarily with the denial of equal protection, ${ }^{7}$ but extended also to include denial of any federally guaranteed right "under color" of any state law or custom. ${ }^{8}$ At the same time Congress permitted the removal to a federal court of any state criminal prosecution when it threatened to deny "equal civil rights." "This last provision has had very limited effectiveness because of the Supreme Court's interpretation of the law as requiring denial of such rights by a state statute. ${ }^{10}$ The most extensive development of federal jurisdiction in relation to state action has come in connection with that provision which deals with action taken under color of state law.

The federal courts have been concerned also with the denial of civil rights by private persons. Here they are restricted by Supreme Court rulings to the effect that many rights are protected by the United States Constitution only against infringement by state action, and redress for wrongs done by private persons can be had only under state law. Hence, attempts by Congress to give federal courts jurisdiction over suits against innkeepers or carriers accused of discrimination based on race were held unconstitutional. ${ }^{11}$.Since the Thirteenth Amendment, which forbids slavery, is broader in scope than the Fourteenth, which guarantees equal protection of the laws, direct federal action can be taken against private persons who practice peonage. ${ }^{12}$

Whether Congress can make lynching by private persons a federal crime is open to serious question. Where state officers are involved federal jurisdiction is clear; otherwise it is doubtful. ${ }^{13}$ Political considerations have, however, prevented the enactment of any law of this kind under which the limits of federal power might be tested.

'Act of March 3, 1887, c. 373, $\$ 1 ; 24$ Stat. 552 (1887), 36 Stat. 1091 (I9II) as amended, 28 U. S. C. $\S_{4 I}(\mathrm{I})(\mathrm{r} 940)$.

-Act of March 3, 1911, cc. 231, 324; 36 STAT. 1091 (I9XI), as amended, 28 U. S. C. $\$ 4$ I(I) (r940).

${ }^{7}$ Act of April 20, 1871, c. $22 \$ \$ 2,6$; 17 STAT. 13, 15 (I871); 36 STAT. 1092 (19II), as amended, 28 U. S. C. $\$ 4$ I (I2), (13), (1940), and Rev. STAT. \$I980 (I875), 8 U. S. C. $\$ 47$ (1940); Act of March I, I875, c. $114, \$ 4,18$ STAT. 336 , Pt. III (1875), 8 U. S. C. $\$ \$ 44,45$ (1940).

Act of April 20, 1871, c. 22, \$1; I7 STAT. 13 (1871), 36 STAT. I092 (IgrI), as amended, 28 U. S. C. $\$ 4 \mathrm{I}(\mathrm{14})$ (1940).

Act of May 31, 1870, c. 114, $\$ \$ 16,18$; 16 STAT. 144; now 36 STAT. $\operatorname{tog} 6$ (I9II), 28 U. S. C. $\$ 74$ (1940).

${ }^{10}$ Kęntucky v. Powers, 20 I U. S. I (1906).

${ }^{12}$ Civil Rights Cases, 109 U. S. 3 (1883).

${ }^{29}$ United States v. Reynolds, 235 U. S. 133 (I914).

${ }^{13}$ See Screws v. United States, 325 U. S. 9I (1945); Milton R. Konvirr, The Constitution and Civil Righrs 74-9o (1947). But see Ex parte Riggins, 134 Fed. 404 (N. D. Ala. rgo4), appeal dismissed, 199 U. S. 547 (1905), where an indictment of private persons was held good because they were charged with the lynching of a Negro while in custody of state officials under charges of crime. 
The federal courts may also proceed directly against violators of rights secured by the United States Constitution. Among the rights so included are the right to vote for members of Congress, ${ }^{14}$ to enter public lands, ${ }^{15}$ to give information with regard to a federal offense, ${ }^{16}$ to be protected from violence while in custody of a federal officer, ${ }^{17}$ and to travel from state to state. ${ }^{18}$

Federal courts, of course, are also concerned with the denial of civil rights by the federal government itself-in the interpretation of statutes challenged as unconstitutional, the review of administrative action, or the exercise of the judicial function itself. We shall not concern ourselves, however, with these problems. The basic substantive questions are the same in the review of both federal and state action. Special procedural problems have arisen, however, in the review of state action, because of the delicate nature of the relation between the Federal Government and the states. These problems are not always thoroughly understood and to some extent the rules underlying them require revision.

Challenge of state action in the federal courts grew, at first, mostly out of postCivil War discrimination against the Negroes' rights to vote, to serve on juries, and generally to become first-class citizens-rights which have still to be fought for. During the last two decades federal jurisdiction has been invoked in aid of other rights, such as freedom of religion and speech. This development has resulted from decisions of the Supreme Court by which most of the specific guarantees of the federal Bill of Rights have been siphoned into the due process clause of the Fourteenth Amendment. ${ }^{19}$

Practically all forms of judicial proceeding have been invoked in efforts to redress grievances: actions at law for damages, suits in equity to enjoin the enforcement of some law or other expected state action, suits for declaratory judgment to define threatened rights, applications for writs of habeas corpus to challenge detention, and criminal prosecutions.

The Supreme Court has had occasion to consider each of these procedures and has announced certain limitations on the effectiveness of most of them. The most serious of these limitations requires application for relief to state courts before address to a federal court-and how often, then, is it futile to try to get action of any kind from the federal court! This particular difficulty arises most often in the field of habeas corpus.

${ }^{14}$ Ex parte Yarbrough, I1o U. S. 651 (1884); United States v. Classic, 313 U. S. 299 (1941).

${ }^{15}$ United States v. Waddell, II2 U. S. 76 (1884).

${ }^{18}$ Motes v. United States, 178 U. S. 458 (1900).

${ }^{17}$ Logan v. United States, I44 U. S. 263 (1892).

${ }^{18}$ See Crandall v. Nevada, 6 Wall. 35 (U. S. 1868 ); United States v. Wheeler, 254 U. S. 281 (1920); Edwards v. California, 3 I $_{4}$ U. S. I60 (I94I).

${ }^{19}$ See Osmond K. Fraenkex; Our Crvil Liberties 46.50 (1944); Wilkinson, The Federal Bill of Rights and the I4th Amendment, 26 Geo. L. J. 439 (1938); Fraenkel, One Hundred and Fifty Years of the Bill of Rights, 23 MrNw. L. Rev. 719 (1939). And see Adamson v. California, 67 Sup. Ct. 1672 (1947). 


\section{The Writ of Habeas Corpus}

The writ of habeas corpus may be used to challenge the propriety of state action on constitutional grounds so basic as to vitiate the conviction attacked. Last-minute attempts to review state convictions by habeas corpus in a federal court failed to save Leo Frank ${ }^{20}$ and Sacco and Vanzetti, ${ }^{21}$ but did save a group of Arkansas Negroes who asserted that their trial had been dominated by mob violence. ${ }^{22}$

The most frequent recent use of the writ has been to explore claims that the convicted defendant has been denied counsel. Ever since the Supreme Court ruled that denial of counsel voids a conviction by a federal court, whatever the circumstances, ${ }^{23}$ attempts have been made, without avail, to obtain a like ruling with regard to state convictions. ${ }^{24}$ But while the absolute protection of the Sixth Amendment does not extend to defendants in state courts, the Supreme Court has ruled that due process of law does require that a state give a defendant ample opportunity to meet an accusation, and has frequently found in particular situations circumstances which make the assignment of counsel essential to the substance of the hearing required by due process. ${ }^{25}$ Direct recourse to the federal courts has rarely been permitted. ${ }^{26}$

The Hawk cases ${ }^{27}$ indicate the difficulty that confronts any one who tries to get relief from the federal courts in the first instance. Hawk maintained he had been convicted of murder without effective representation by counsel and that perjured evidence had been used against him with the connivance of the prosecutor. The state Supreme Court had refused relief, on the ground that application should have been made to a lower state court; various lower federal courts had also refused to act. The Supreme Court, in 1944, upheld their refusal on the ground that Hawk had not exhausted his remedies in the state courts. After an attempt to do just this failed, the Supreme Court ruled that the state courts should have given Hawk a hearing. But the state court still refused to grant a hearing, this time on the ground that Hawk had mistaken his remedy-he should have used the writ of coram nobis, not the writ of habeas corpus. ${ }^{28}$ When he then applied to a federal

${ }^{20}$ Frank v. Mangum, 237 U. S. 309 (x915), Holmes and Hughes, dissenting.

${ }^{21}$ Sce Osarond K. Fraenkel, Thi Sacco-Vanzetti Case 178-i82 (i93i).

${ }^{22}$ Moore v. Dempsey, 26 r U. S. 86 (1923).

${ }^{23}$ Johnson v. Zerbst, 304 U. S. 458 (1938). Actually the point first arose in a state case, the first of the Scottsboro appeals, Powell v. Alabama, 287 U. S. 45 (1932).

${ }^{24}$ From Betts v. Brady, 316 U. S. 455 (1942) to Foster v. Illinois, 67 Sup. Ct. 1716 (1947).

${ }^{25}$ As in De Meerler v. Michigan, 329 U. S. 663 (1947). Marino v. Ragen, 68 Sup. Ct. 240 (U. S. 1947).

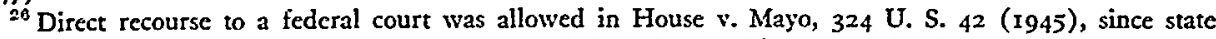
remedies had been exhlausted. But the court ruled against petitioner on the facts: 63 F. Supp. 169 (S. D. Fla. 1945), affd, 151 Fed. Io14 (C. C. A. 5th 1945), cert. denied, 327 U. S. 814 (1946).

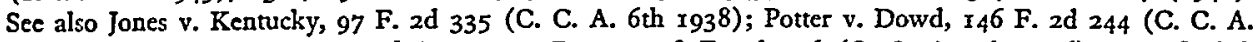
7 th 1944). United States ex rel. Rooney v. Ragen, 158 F. 2 d 346 (C. C. A. 7 th 1946), cert. denied, 33 I U. S. 842 (I947).

${ }^{27}$ Ex parte Hawk, 321 U. S. II4 (I944); Hawk v. Olson, 326 U. S. 27 (1945).

${ }^{28}$ The essential differences are: the writ coram nobis can be granted only by the court in which the ionviction was had; in some states it must be asked for within a limited time; it is often not appealable. 
court, he was met by the contention that he had not yet exhausted his state remedies. $^{29}$ And the Hawk case is not unique, for in many states it is not clear what remedy exists for challenging convictions of this kind. ${ }^{30}$

A particularly glaring instance of the consequence of the rule requiring exhaustion of state remedies was the Mooney case. Years after his conviction in California for murder, Mooney asserted that the chief witness against him was a perjurer, suborned by the district attorney. After he unsuccessfully sought a writ of habeas corpus in a lower federal court, the Supreme Court held that there was merit in his contentions and that the use of testimony known to be false was a denial of due process. $^{31}$ But it ruled also that Mooney must seek redress in the state courts. Accordingly, it was the California court which passed on the factual issue underlying Mooney's case, and, as was to be expected, that issue was decided against him at the hearing. On appeal, the California Supreme Court accepted the result with but one dissent, and this time the United States Supreme Court refused to interfere. ${ }^{32}$ Justice for Mooney was left to belated executive clemency.

As it now stands, the rule that application must first be made to the state courts in effect destroys the right to apply to the lower federal courts at all. If the state court grants a hearing and decides the facts against the contention of the convicted man, no other court is likely to review this determination or grant another hearing. If the state court refuses a hearing on the ground the claim made by the accused raises no constitutional issue and the Supreme Court refuses to review on certiorari, it is pretty certain no lower federal court will thereafter grant relief and most unlikely that the Supreme Court will then take the case. ${ }^{33}$ It is only where the state court confesses itself powerless under state procedure to grant relief that direct application to the federal court is possible. ${ }^{34}$ This is seldom likely to happen; hence the right to apply to a lower federal court has become an illusory one.

Further, since the state courts are allowed to pass upon the factual issues, the chance of real relief to a person who contends that state officials have misconducted

On the other hand this writ is not limited to cases in which the aggrieved person is in custodgi. See Gayes v. New York, 67 Sup. Ct. I7II (1947); Woods v. Nierstheimer, 328 U. S. 21 I (1946).

${ }^{20}$ Hawk v. Olson, 66 F. Supp. 195 (D. Nebr. 1946).

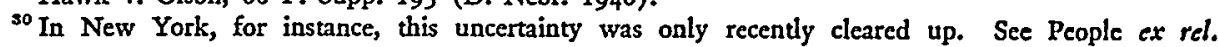
Wachowitz v. Martin, 293 N. Y. 36I (1944); Matter of Hogan, 295 N. Y. 92 (1946). The unsatisfactory situation which for a long time has existed in Illinois is discussed by Mr. Justice Rutledge, concurring, in Marino v. Ragen, 68 Sup. Ct. 240, 241 (U. S. 1947).

${ }^{21}$ Mooney v. Holahan, 294 U. S. 103 (1935).

${ }^{32}$ Mooney v. Smith, ro Cal. 2d I, 73 P. 2d 554 (1937); id. 305 U. S. 598 (1938).

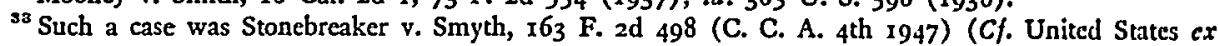
rel Monsky v. Warden of Clinton State Prison, r63 F. 2d 978 (C. C. A. 2d 1947)); and it has been held that state remedies have not been exhausted until review by the United States Supreme Court has been sought, Gordon v. Scudder, I63 F. 2 d 518 (C. C. A. 9th 1947).

se As to Florida, see House v. Mayo, 324 U. S. 42 (1945); as to Indiana, see Potter v. Dowd, I47 F. 2 d 244 (C. C. A. 7 th 1944). In White v. Regan, 324 U. S. 760 (1945), the Court pointed out that application for certiorari is not a prerequisite to recourse to a lower federal court where the state court decision might have rested on a non-federal ground. But as to when state remedies have not been exhausted see also Woods v. Nierstheimer, 328 U. S. 21 I (x946). 
themselves is likewise illusory. It is too much to expect wholly impartial justice when one state official sits in judgment on another. Therefore, in situations like this, the determination of the factual issue by a federal authority seems likelier to be fair. Congress should change the existing rule so as to permit application to a federal court in the first instance when a claim is made that a federal right has been denied by improper action of state officials, whether prosecutors or judges. In this respect the proposed revision of the Judicial Code, ${ }^{33}$ which has already passed the House of Representatives, is defective. It proposes that application to a federal court may be made in the first instance only where there is no "adequate" remedy available in state courts, or where state courts have denied a fair adjudication.

That formulation has been criticized also on the ground that the use of the word "adequate" is likely to produce further litigation and uncertainty in the field. Suggestions have come in to the effect that the words of the Johnson Act, ${ }^{36}$ which deals with injunctions against state rate schedules, be employed here, namely: "plain, speedy and efficient." Surely if doubt exists regarding what remedy the state courts offer, relief should be had in the first instance in a federal court. It should no longer be possible to buffet a litigant like Hawk from one court to another because no one seems quite sure where the proper remedy for him lies.

\section{Interference With State Action}

The most frequent instances of federal jurisdiction are attempts to prevent state authorities from carrying out certain announced policies. In some cases this involves enjoining criminal prosecutions; in others, it may involve suits for declaratory judgment with regard to the meaning of a state law.

Where no particular problem exists concerning the meaning of the state law, federal jurisdiction is plain. This was the basis on which the Witnesses of Jehovah successfully sought to enjoin the enforcement by school authorities, in various parts of the country, of their requirement that all children participate in flag salute ceremonies or be expelled. ${ }^{37}$ Lower federal courts have permitted injunction suits under a variety of other circumstances. Thus a suit was sustained which sought to prevent segregation of Mexican children in California schools, even though the acts of the authorities were held to be contrary to state law. ${ }^{38}$ Suits have also been successfully brought to correct discriminations in teachers' salaries due to their race. ${ }^{39}$ On the other hand, recourse to federal çourts has been denied when the relief sought has been purely political-such as to restrain state officers from arranging for an election under districting challenged as violating the Constitution. ${ }^{40}$

${ }^{35}$ H. R. 3214, 8oth Cong., rst Sess. (1947).

${ }^{30}{ }_{4} 8$ STAT. 775 (1934), amending 28 U. S. C. $\$_{4} \mathrm{x}(\mathrm{x})$. See Driscoll v. Edison Co., 307 U. S. 104 (1939).

${ }^{37}$ Minersville School District v. Gobitis, 310 U. S. 586 (1940); Barnette v. West Virginia State Board of Education, 319 U. S. 624 (1943).

${ }^{33}$ Westminster School Dist. v. Mendez, 16I F. 2d 774 (C. C. A. 9th 1947).

${ }^{30}$ Alston v. School Board, II2 F. 2 d 992 (C. C. A. $4^{\text {th }}$ 1940); Thompson v. Gibbes, 6o F. Supp. 872 (E. D. S. C. 1945).

${ }^{40}$ Colegrove v. Green, 328 U. S. 549 (1946); cf. Blackman v. Stone, Ior F. 2 d 500 (C. C. A. $7^{\text {th }}$ 
When, however, the meaning of the state statute involved is unclear, particularly when attempts are made immediately upon passage to prevent its enforcement, the situation alters. In such cases as these the Supreme Court has imposed the limitation that the state court should be given a chance to limit its application so as, perhaps, to avoid any infringement of constitutional right.

This rule, well established in cases involving ordinary property rights, was given definite application to civil liberties in a case involving the Witnesses of Jehovah. Many municipalities had attempted to restrict the activities of this sect on the public streets, by applying ordinances restricting distribution of leaflets and by requiring license fees in connection with distribution. The Supreme Court had made numerous rulings for Jehovah's Witnesses in direct review of convictions for violating these types of ordinances. ${ }^{41}$ In one situation, however, the witnesses sought to prevent prosecution by suit for injunction. In Douglas v. Jeannette, ${ }^{42}$ a unanimous Supreme Court held this might not be done. Chief Justice Stone stated that a federal court should not attempt in advance to pass on the various issues which might arise. He pointed out that relief by injunction had been allowed in the CIO's case against Mayor Hague of Jersey City ${ }^{43}$ because, in that case, local officials forcibly broke up meetings and deported participants from the state, without instituting legal proceedings in which those affected could have challenged the constitutionality of the acts they complained of.

The same rule was applied in a case instituted by the American Federation of Labor to challenge an amendment to the Florida Constitution outlawing the closed shop. In that case, ${ }^{44}$ however, the majority of the Supreme Court reached the conclusion that the federal court should retain jurisdiction of the action until the Florida courts had interpreted the constitutional provision. Why jurisdiction was retained here but was not in the case of the Witnesses of Jehovah does not become altogether clear in the opinion of Mr. Justice Douglas, although he does refer to the fact that proceedings were threatened against a large number of unions. The distinction seemed insufficient to the Chief Justice, who considered the two cases alike and believed the suit should have been dismissed. On the other hand, Justice Murphy thought the issue was so clear that it should have been passed upon by the federal court without awaiting action by the state.

The rule remains the same though the application be for declaratory judgment

1939); Cook v. Fortson, 329 U. S. 675 (1946). Original jurisdiction in these cases was in a special three judge court under 28 U. S. C. $\$ 380$ ( 5940$)$, because state statutes, not merely municipal ordinances, were being attacked.

II Schneider v. Irvington, 308 U. S. 147 (1939); Murdock v. Pennsylvania, 319 U. S. 105 (1943).

${ }^{\star 2} 319$ U. S. 157 (1943). $\quad{ }^{13}$ Hague v. C.I.O., 307 U. S. 496 (1939).

14 A. F. of L. v. Watson, 327 U. S. 582 ( 1946$)$. Original jurisdiction in this case whs in a special three judge court under 28 U.S. C. $\$ 380$ (1940), because a state statute, not merely a municipal ordinance, was being attacked. See also Traffic Telephone Workers' Federation of New Jersey v. Driscoll, 72 F. Supp. 499 (D. N. J. 1947), appeal dismissed, Justices Black and Rced dissenting, 68 Sup. Ct. 22I (U. S. 1947). There a state suit was brought as contemplated under Section 380 and the federal suit stayed to await the outcome of the state suit. 
rather than an injunction. Thus, the Supreme Court refused to pass on the merits of challenges by labor organizations against an Alabama statute regulating their activities. ${ }^{40}$ While the suits in those cases had been instituted in the state courts, the Supreme Court made it plain that the same rule would apply to such a suit brought in the federal courts.

It seems clear, therefore, that the federal courts can be used to protect constitutional rights only after a doubtful state statute has been defined by the highest state court. Here again the restriction has made the direct appeal to the federal courts largely fruitless. Normally, the way to review the decision of the state court denying a claimed federal right would be to seek direct review of that decision in the United States Supreme Court. There are, of course, circumstances under which perhaps the federal courts might take jurisdiction at the behest of someone who had not been a party to the earlier proceedings. And however restrictive the present rule may be, it is not open to serious objection, because the state court is being called upon to interpret its own statute, not to pass on contested facts. If the interpretation of the statute is such as to prevent denial of federal right then no harm has been done; if the opposite result is reached the question still remains open for the United States Supreme Court to pass on.

\section{Damage Suits}

Since an action at law for damages does not seek to compel future action or to undo the past, it is not subject to any of the restrictions we have been discussing. The question to be determined in such a suit is whether the act complained of violated a federal right. This involves deciding whether the act took place and whether, if it did, a federal right was infringed-an issue of fact and one of law. It is the federal court which determines both questions.

In order to get into the federal court it is, of course, necessary to comply with the jurisdictional requirements of the federal Judicial Code. Either the amount claimed must exceed $\$ 3,000$ or the case must present one of those special situations in which no jurisdictional amount is required: i.e., it must arise out of a conspiracy to deny equal rights or it must concern an act committed under "color" of state law or custom. ${ }^{46}$

What constitutes such "color" has given rise to much controversy. The law on the subject has been defined chiefly in criminal cases, but is, of course, equally applicable to civil actions for damages. The Supreme Court has definitely ruled that an act is done under color of state law even though not authorized by state law, so

${ }^{45}$ A. F. of L. v. McAdory, 325 U. S. 450 (1945); C. I. O. v. McAdory, 325 U. S. 472 (I945); cf. Hill v. Florida, 325 U. S. 538 (1945). Suits for declaratory judgment were allowed, however, in connection with claims for the right to vote in primaries, Ellmore v. Rice, 72 F. Supp. 516 (E. D. S. C. 1947), and in connection with right to a legal education: Wrighten v. Board of Trustees, 72 F. Supp. 945 (E. D. S. C. r947). Basis for the latter case was of course Missouri ex rel. Gaines v. Canada, 305 U. S. 337 (1938), although that was an application for a mandamus, and basis for the former was Smith v. Allwright, 321 U. S. 649 (1944), although that was an action for damages.

${ }^{10}$ See 36 Stat. rog2 (IgII), as amended, 28 U. S. C. $\$ 4$ I.(I2), (I3), (I4) (I940). 
long as it is done by state officials purporting to act pursuant to authority given them by law. ${ }^{47}$

Damage suits, of course, have been brought in a great variety of circumstances. The courts have upheld actions of this kind brought for denial of the right to vote for federal office, ${ }^{48}$ and also for conspiracy to deny the equal protection of the laws, ${ }^{49}$ but not to deny due process. ${ }^{50}$

The Supreme Court was recently confronted with the problem whether or not a suit for damages could be brought for unlawful search and seizure. ${ }^{51}$ While, in the particular case, the suit was against federal officials, the same problem might arise concerning state officials. Here the majority of the Supreme Court did not finally pass on the question, but merely ruled that the District Court had jurisdiction to determine it. Chief Justice Stone and Justice Burton believed no right to bring suit existed, since neither the constitutional provision nor any act of Congress afforded a remedy to the person whose rights had been invaded.

The lower federal courts have upheld their jurisdiction in a number of interesting situations. In one case a school teacher sued his principal on the ground that the latter had improperly caused his discharge for absence from duty while serving on a federal jury. ${ }^{52}$ In another, a Negro sued to recover damages because he had been denied the right to training as a librarian in a school maintained by a municipality. And a complaint was upheld which sought damages for unlawful arrest where it was alleged that the arrest had been made under color of a state law affecting interstate rendition. ${ }^{54}$

On the other hand, it was held that no basis existed for a suit alleging conspiracy to prevent employment in the WPA, because plaintiff had no "absolute right" to such employment. ${ }^{55}$ Nor can a federal court entertain a suit for damages because of failure of state officers to certify the plaintiff as nominee in an election, there being no property right involved. ${ }^{56}$ Although a claim was made in that case that the denial of certification was based on discrimination, the court rejected that claim over the dissent of Justices Black and Douglas.

"7 United States v. Classic, 313 U. S. 299 (194I); United States v. Screws, 325 U. S. 91 (1945).

${ }^{48}$ Lane v. Wilson, 307 U. S. 268 (1939); Myers v. Anderson, 238 U. S. 368 (1915).

${ }^{49}$ As in Smith v. Allwright, 32x U. S. 649 (1944), for refusing Negroes the right to vote in a primary.

${ }^{-50}$ Mitchell v. Greenough, roo F. 2 d 184 (C. C. A. 9th 1938), cert. denied, 306 U. S. 659 (1939). But in Refoule v. Ellis, 74 F. Supp. 336 (N. D. Ga. 1947), the court granted a preliminary injunction to restrain infringements of due process such as improper questioning to obtain a confession and harassment by arrest without warrant.

${ }^{51}$ Beli v. Hood, 327 U. S. 678 (1946). Later the District Court held that no cause of action existed under federal law to recover damages because of an unlawful search and seizure, even when the wrongdoers werc federal officers. 7I F. Supp. 813 (S. D. Cal. 1947).

${ }^{62}$ Bomar v. Keyes, I62 F. 2 d 136 (C. C. A. 2 d 1947).

${ }^{53}$ Kerr v. Enoch Pratt Free Library, 149 F. $2 d$ 212 (C. C. A. $4^{\text {th }}$ 1945), cert. denied, 326 U. S. $72 x$ (1945).

st Picking v. Pennsylvania R. R., I5x F. $2 d 240,152$ id. 753 (C. C. A. 3d 1945).

${ }^{8 x}$ Love v. Chandler, 124 F. 2d 785 (C. C. A. 8th 1942).

${ }^{60}$ Snowden v. Hughes, 321 U. S. I (1944), cf. Shunders v. Wilkins, 152 F. $2 d 235$ (C. C. A. $4^{\text {th }}$ 1945), cert. denied, 328 U. S. 870 (1946). 
In one respect the law might well be changed with regard to damage suits. There seems no reason why vindication of constitutional rights in the federal courts should depend upon the amount involved where civil liberties are at issue, whatever may be the propriety of keeping small property claims out of these courts. Congress has already recognized the soundness of this principle in certain sorts of civil liberties cases. It should extend the right of direct resort to the federal courts to all civil liberties cases arising out of the federal Constitution, regardless of the amount in controversy.

\section{Criminal Prosecution}

In addition to the civil remedies open to aggrieved individuals themselves, there is always the possibility that the aid of the prosecuting arm of the federal government may be invoked. Since Attorney General Murphy set up a Civil Rights section in the Department of Justice, action in this field has been coordinated. In consequence there has been a considerable increase in the number and extent of federal prosecutions. Unfortunately, the area within which these can be conducted is a narrow one.

Federal prosecution for violation of civil rights rests, in the main, on laws enacted to implement the post-Civil War amendments to the Constitution, the Thirteenth, Fourteenth, and Fifteenth. The first of these laws was the Enforcement Act of 1870.57 Although most of its provisions were repealed, ${ }^{58}$ several sections still remain. One of these ${ }^{69}$ punishes as a crime any conspiracy to deprive a citizen of rights or privileges secured by the Constitution or laws of the United States. While this section protects only citizens and applies only to conspiracies, it is not limited to action by state officers. ${ }^{60}$ Another provision still in effect ${ }^{61}$ protects all persons and is not restricted to conspiracies, but it can be invoked only when the accused has acted under color of a state law or custom. The third provision also still in existence $^{62}$ punishes interference with the right to vote because of race or color. Congress has also passed laws punishing peonage, ${ }^{63}$ which are applicable to private persons as well as to state officials. ${ }^{64}$

Since the Civil Rights Law does not specify what federally secured rights are

${ }^{27}$ I6 STAT. 140 (1870), 36 STAT. 1092 (19IX), 28 U. S. C. $\$ 4$ I (II) (1940).

${ }^{88} 28$ StAT. 36 (I894), 36 Stat. 1096 (Y9II), as amended, 39 Stat. 532 (I9I6), 28 U. S. C. $\$ 74$ (1940), 35 STAT. I153 (1909), 18 U. S. C. $\$ \$ 572,573$ (1940).

E0 35 Stat. 1092 (1909), 18 U. S. C. $\$ 51$ (1940). See Mirton R. Konutrz, The Constitution AND Civil Righrs 28-47 (1947).

${ }^{\circ}$ United States v. Ellis, 43 F. Supp. 32 (W. D. S. C. 1942).

- 35 Stat. 1092 (1909), i 8 U. S. C. $\$ 52$ (1940). See MiLton R. Konvitz, The Constitution AND Clvil Rights 47-73 (1947).

${ }^{02}$ REv. STAT. \$2004 (I875), 8 U. S. C. \$31 (1940).

${ }^{03}$ Rev. Stat. $\$ 1990$ (1875), 8 U. S. C. $\$ 56$ (I940); 35 Stat. 1138 (1909), I8 U. S. C. $\$ 421$ (1940).

- Pierce v. United States, $4_{46}$ F. 2 d 84 (C. C. A. 5th 1944), cert. denied, 324 U. S. 873 (1944). 
protected against interference, it was argued, in Screws v. United States, ${ }^{05}$ that the law was too vague to be enforced. The majority of the Supreme Court ruled otherwise. Mr. Justice Douglas pointed out that these rights had become defined by successive decisions of the court. It had been settled that for a state officer to maltreat a person after his arrest was a denial of due process. ${ }^{60}$ Therefore, any state officer who committed such an act in the knowledge it was wrong could be punished. But it was necessary to establish that the violation of right had been willful. The majority, therefore, reversed the conviction, since they believed the jury had been insufficiently instructed. Three of the justices (Roberts, Frankfurter, and Jackson) thought that the indictment should have been dismissed altogether, both because the statute was too vague and because the acts complained of had not been committed under color of state law. Justices Rutledge and Murphy thought that the conviction should have been affirmed, but Justice Rutledge concurred with the decision of the four justices who thought there should be a new trial only because, otherwise, the case would remain undisposed of. Both these justices maintained there could be no doubt the state officials knew they had no right to do what they did. Mr. Justice Murphy pointed out that the question of the sufficiency of the judge's charge had not been raised in the lower courts and that there was no need for any explicit charge on the subject of willfulness.

The effect of the majority decision has been unfortunate, because the stress on the necessity for willful violation of constitutional rights makes it easy for a judge unsympathetic to the the prosecution to induce a jury to acquit. This is what actually happened on the retrial of the Screws case.

Existing law would be much improved by the simple enactment that all interferences with federally secured rights are criminal, replacing the present law which condemns only those resulting from conspiracy and those carried out under color of state law. This change would not, of course, be very far-reaching; but there is no reason for not making it. Congress could also strengthen the present laws dealing with the suffrage, particularly by making it an offense to interfere in any way with presidential elections (to overcome a lower court's ruling ${ }^{\text {b7 }}$ that existing laws do not cover these). Specific legislation may also be desirable in order to broaden the base for dealing with primary elections, a base now somewhat limited by the Supreme Court in the Classic case. ${ }^{68}$

Congress might further use the commerce power both by prohibiting segregation by interstate carriers and by prohibiting discrimination by labor unions or employers engaged in interstate commerce.

It has been suggested that it might be easier to obtain convictions if the Civil

๑5 325 U.. S. 9 I (1945).

${ }^{\circ 8}$ Culp v. United States, r3I F. 2d 93 (C. C. A. 8th I942); Catlette v. United States, 132 F. 2d 902 (C. C. A. $4^{\text {th }}$ 1943).

or Walker v. United States, 93 F. 2 d 383 (C. C. A. 8th I937), cert. denied, on appeal of defendants, 303 U. S. 655 (1938).

${ }_{313}$ U. S. 299 (r94r). 
Rights Law were amended so as to avoid the necessity of persuading juries that the defendants have willfully sought to invade constitutional rights. This could be accomplished in two ways: by simply deleting the word "willful" from the statute, or by replacing the present law with a new one making it a crime to violate certain specific rights. The opinions in the Screws case ${ }^{69}$ cast grave doubt upon the constitutionality of the first proposal. The second would no doubt remove the argument that the law is too vague to be enforceable, an argument which led the majority of the Supreme Court to insist the offense must be a willful one. Such an amendment would specify precisely those federally secured rights, interference with which would constitute a crime. The suggestion is persuasive, but not, I think, sound. For, while specific laws might produce more convictions for the particular offenses described, necessarily there would be others left out, either because Congress had not thought of them at the time or because of the difficulty of obtaining Congresssional agreement that they should be included.

\section{ConcLusion}

It should be borne in mind that modern experience shows us the courts are not always the best instruments for securing civil rights. Even in relatively enlightened states, such as New York, conventional methods of law enforcement by civil suit or criminal prosecution have proved ineffective. And when the legislature of New York decided to do something effective about discrimination in employment it used the administrative procedure already found useful in the field of labor relations. Congress may follow suit and create a permanent Fair Employment Practices Commission. Later similar machinery may be established to deal with other areas of discrimination, such as housing and education. Administrative methods may even come to be applied to the elusive subject of restrictions on voting. In all these fields action by administrative agencies should be much more effective than the haphazard results obtainable from the privately maintained law suit.

If the shift to administrative action occurs in these large areas of civil liberties, then the role of the lower federal courts as fact finders will diminish. Yet their role as interpreters of the law and as guardians of fair procedure will always remain, subject, of course, to the final say of the Supreme Court. Indeed, in dealing with questions of the procedure of state courts, the function of the lower federal courts may even be increased if, as suggested, they are given power to pass on the facts when a claim of wrongdoing by state officials is made. However their scope be changed, they will continue to exercise an important function in assuring that the states respect the provisions of the federal Constitution and the laws which protect the civil rights of the individual.

•" 325 U. S. 9I (1945). 